
\title{
25 Research Soure \\ Identification of Metal Pollutants in Ambient Air (Case Study: West Surabaya, East Java, Indonesia)
}

\section{Tresta Nurina Ciptaningayu}

Institut Teknologi Sepuluh Nopember

Arie Dipareza Syafei ( $\boldsymbol{D}$ dipareza@enviro.its.ac.id)

Institut Teknologi Sepuluh Nopember https://orcid.org/0000-0001-6967-8109

Muhayatun Santoso

BATAN: Badan Tenaga Nuklir Nasional

Joni Hermana

Institut Teknologi Sepuluh Nopember

Rachmat Boedisantoso

Institut Teknologi Sepuluh Nopember

Abdu Fadli Assomadi

Institut Teknologi Sepuluh Nopember

\section{Research}

Keywords: Conditional Probability Function, Heavy metal, Industry, Particulate matter, Positive Matrix Factorization

Posted Date: December 23rd, 2020

DOI: https://doi.org/10.21203/rs.3.rs-133553/v1

License: (c) (1) This work is licensed under a Creative Commons Attribution 4.0 International License. Read Full License 


\section{Abstract}

Surabaya City, especially the western area of Surabaya, is utilized for industrial space, warehousing, final disposal sites (FDS), and port areas. Activities in these areas produce emissions, particularly $\mathrm{PM}_{2.5}$ (particulate matter smaller than $2.5 \mu \mathrm{m}$ ) and $\mathrm{PM}_{10}$ (particulate matter smaller than $10 \mu \mathrm{m}$ ). $\mathrm{PM}_{2.5}$ and $\mathrm{PM}_{2.5-10}$ contain metals and can cause respiratory disorders and death. Therefore, it is necessary to determine the concentrations of $\mathrm{PM}_{2.5}$ and $\mathrm{PM}_{2.5-10}$ and the heavy metals contained in the PMs. Sampling for $\mathrm{PM}_{2.5}$ and $\mathrm{PM}_{2.5-10}$ was conducted using a Gent Stacked Filter Unit (Gent SFU) every six (6) days between October 2019-April 2020. The samples were then analyzed using gravimetry to determine mass concentrations of $\mathrm{PM}_{2.5}$ and $\mathrm{PM}_{10}$ and analyzed using XRF (X-Ray Fluorescence) to determine the elements contained within $\mathrm{PM}_{2.5}$ and $\mathrm{PM}_{2.5-10}$ and their concentrations. The elemental concentrations were used as Positive Matrix Factorization (PMF) inputs to identify potential pollutant sources. The results of the PMF analysis were then used to determine the source locations of pollutants by using a Conditional Probability Function (CPF). The observed concentrations of $\mathrm{PM}_{2.5}$ and $\mathrm{PM}_{10}$ are $11.47 \mu \mathrm{g} / \mathrm{m}^{3}$ and $27.49 \mu \mathrm{g} / \mathrm{m}^{3}$, or $11.45 \mu \mathrm{g} / \mathrm{Nm}^{3}$ and $26.98 \mu \mathrm{g} / \mathrm{Nm}^{3}$. 18 elements are identified in the PM, namely $\mathrm{Na}$, $\mathrm{Mg}, \mathrm{Al}, \mathrm{Si}, \mathrm{S}, \mathrm{K}, \mathrm{Cl}, \mathrm{Ca}, \mathrm{Ti}, \mathrm{V}, \mathrm{Cr}, \mathrm{Mn}, \mathrm{Fe}, \mathrm{Ni}, \mathrm{Cu}, \mathrm{Zn}, \mathrm{Br}$, and $\mathrm{Pb}$. Potential sources of $\mathrm{PM}_{2.5}$ pollutants are a combination of $\mathrm{Cu}$ industries, biomass burning, $\mathrm{Ni}$ industries, non-ferrous metal industries, transportation activities, iron and steel industries, construction activities, dust, port activities, and $\mathrm{Pb}$ industries. Potential sources of $\mathrm{PM}_{2.5-10}$ pollutants are construction activities, dust, transportation activities, non- ferrous metals industries, and Ni industries. The estimated source locations of the pollutants contributing to $\mathrm{PM}_{2.5}$ and $\mathrm{PM}_{2.5-10}$ are spread out from north to southwest. Based on this analysis, the concentrations of $\mathrm{PM}_{2.5}, \mathrm{PM}_{2.5-10}$, and metal elements met air quality standards.

\section{Introduction}

Particulate matter (PM) is one indicator of air pollution produced from anthropogenic and natural sources [1]. PM is categorized into fine $\mathrm{PM}$, with a diameter smaller than $2.5 \mu \mathrm{m}$, and coarse $\mathrm{PM}$, with a diameter of 2.5-10 $\mu \mathrm{m}$. PM contains heavy metals such as $\mathrm{Al}, \mathrm{As}, \mathrm{Ba}, \mathrm{Br}, \mathrm{Ca}, \mathrm{Cl}, \mathrm{Co}, \mathrm{Cr}, \mathrm{Cu}, \mathrm{Fe}, \mathrm{Hg}, \mathrm{I}, \mathrm{K}, \mathrm{Mg}, \mathrm{Na}, \mathrm{Ni}, \mathrm{P}$, $\mathrm{Pb}, \mathrm{S}, \mathrm{Sc}, \mathrm{Si}, \mathrm{Se}, \mathrm{Sr}, \mathrm{Ti}, \mathrm{V}$, and $\mathrm{Zn}$. Generally, the elements $\mathrm{Pb}$ and $\mathrm{Zn}$ are emitted by industry and traffic [24]. These heavy metals can have harmful effects on human health, such as various respiratory diseases, anemia symptoms, decreased immune system strength, autism symptoms, lung cancer, and death [5]. Research in major cities states that an increase of $10 \mu \mathrm{g} / \mathrm{m}^{3}$ in $\mathrm{PM}_{10}$ increases mortality by $0.5 \%$, mostly caused by lung and heart disease [6]. Fine particulates contribute to mortality rates caused by health problems related to air pollution [5].

Arsenic exposure is associated with an increased risk of skin and lung cancer. Cadmium is associated with kidney and bone damage and has been identified as a potential carcinogen in humans, and is a potential cause of lung cancer, neurobehavioral effects in fetuses, infants, and children, and increased blood pressure in adults [7]. Chromium causes respiratory and digestive system disorders, while 
manganese at high doses causes nervous system disorders. Nickel, known as a carcinogen, also has non-cancerous effects, such as disorders in the endocrine system [8]. The risk of heavy metal exposure through inhalation can affect both children and adults. In Delhi, India, high mortality risk is due to the $\mathrm{Pb}$ content in children's blood as well as cases of cancer due to $\mathrm{Cd}, \mathrm{Cr}$, and $\mathrm{Ni}$ [9]. The potential health risks of $\mathrm{Pb}$ have a serious impact on children, and the $\mathrm{Pb}$ found in $\mathrm{PM}_{2.5}$ plays an important role in myocardial toxicity [10].

The main sources of heavy metal pollution in rural areas are coal-burning, road dust, and soil, while the sources of pollution in urban areas are industrial emissions, road dust, soil, and vehicles [11]. The $\mathrm{Cu}, \mathrm{Zn}$, $\mathrm{Cd}, \mathrm{Pb}$, and $\mathrm{Hg}$ contained in $\mathrm{PM}_{2.5}$ at Tianjin, China, were identified from anthropogenic sources such as vehicles, waste, and coal-burning [12]. The $\mathrm{Pb}$ concentrations found in fine particulates and coarse particulates were higher in the industrial area compared to the residential area in Serpong, Indonesia. In one study, the sources of pollutants in Serpong were found to be emissions from diesel vehicles (30\%), oil and power plants $(26 \%)$, road dust $(17 \%)$, biomass combustion mixed with road dust $(15 \%)$, and the lead industry mixed with road dust (12\%) [3]. The ambient air in Surabaya has higher $\mathrm{Zn}$ and Pb compared to other cities. The sources of pollutants were emissions from biomass, vehicles, soil, lead industry, zinc industry, and ferrous industry [13].

Surabaya City, especially its western area, is utilized as industrial areas, warehousing areas, final disposal sites (FDS), and port areas. Activities in those areas produce $\mathrm{PM}_{2.5}$ and $\mathrm{PM}_{10}$ emissions which contain metals. These particulates cause respiratory disorders and death. Therefore, research on the content of heavy metals in particulates in West Surabaya is needed.

\section{Materials And Methods \\ 2.1 Sampling method}

Sampling was conducted from October 15, 2019 - April 6, 2020, for 24 hours every six days, around industrial and warehousing areas in West Surabaya. A total of 32 samples were collected at the sampling site in Osowilangun Terminal. Figure 1 shows the sampling location $\left(7^{\circ} 13^{\prime} 7.5^{\prime \prime} \mathrm{S}, 112^{\circ} 39^{\prime} 9.75^{\prime \prime} \mathrm{E}\right)$.

A Gent Stacked Filter Unit (SFU Gent) was used to collect ambient $\mathrm{PM}_{2.5}$ and $\mathrm{PM}_{2.5-10}$ samples. It was placed on the roof of the building at a height of $3 \mathrm{~m}$ from the ground level. The SFU Gent is a dichotomous sampler that can collect airborne particulates with a size of 2.5-10 $\mu \mathrm{m}$ and particles smaller than $2.5 \mu \mathrm{m}$. There is a cut-off stage inlet impactor system that allows only dust measuring less than $10 \mu \mathrm{m}$ to enter, while dust measuring more than $10 \mu \mathrm{m}$ will fall. The flow rate used in the SFU Gent was $18 \mathrm{~L} / \mathrm{min}$ [14]. Inside the SFU Gent, filter tapes were used to place polycarbonate paper filters which had a diameter of $47 \mathrm{~mm}$. Two types of filters were used: coarse filters and fine filters. The coarse filters were used to collect particles measuring $2.5-10 \mu \mathrm{m}$, while fine filters were used to collect particles smaller than $2.5 \mu \mathrm{m}$ All filters were conditioned for 24 hours in a cleanroom to control the temperature and humidity before use. The temperature and humidity used for conditioning were between $18-25^{\circ} \mathrm{C}$ 
and $40-60 \%$. Each filter was then weighed to determine the initial weight. Sampling was conducted by installing both types of filters on the filter tape.

A Kestrel 5500 meter was used to analyze the wind direction and wind speed. Figure 2 shows the SFU Gent container, flow rate meter and pump, Kestrel meter, filters, and cassette filter. In addition to measuring primary data, this study also needed secondary data such as industrial data for West Surabaya and Gresik Regency and rainfall data from the Meteorological Agency of Climatology and Geophysics (BMKG).

\subsection{Analysis of Samples}

The concentrations of fine and coarse particulates were analyzed using the gravimetric method. The $\mathrm{PM}_{2.5}$ concentration was calculated by subtracting the initial sample weight $(\mathrm{mg})$ from the final sample weight $(\mathrm{mg})$, the result of which was then divided by the volume of air $\left(\mathrm{m}^{3}\right)$ that traveled through the filter. The concentration of $\mathrm{PM}_{10}$ was calculated from the sum of the concentrations of $\mathrm{PM}_{2.5}$ and $\mathrm{PM}_{2.5-10}$. Furthermore, the samples were analyzed using XRF (X-Ray Fluorescence) with an Epsilon 5 PANanalytical to determine the elemental content and concentrations. XRF was used to identify the various elements in particles and to generate data sets of the concentrations of 25-30 elements [15].

\subsection{Positive Matrix Factorization}

A receptor model is a mathematical approach to measuring the contribution of a source based on the composition of the source. This principle is used to identify the elements and types of emission sources from airborne particulates in the atmosphere. A data set is called the Xij matrix, where $i$ is the number of samples, and $\mathrm{j}$ is the measured species/element concentration. The objective of the model receptor is to solve the chemical mass balance between the measured species concentration and the source profile, such as in Eq 1 and 2,

$$
\begin{aligned}
& X i j=\sum_{k=1}^{p} G i k F k j+e i j \text { or } \mathrm{X}=\mathrm{GF}+\mathrm{E} \\
& e i j=X i j-\sum_{k=1}^{p} G i k F k j
\end{aligned}
$$

where $\mathrm{p}$ is the number of factors, $\mathrm{F}$ is the source profile, $\mathrm{G}$ is the number of masses that contributed to each factor for each sample, and eij is the residual for each species.

The identified elements are arranged in the $X$ matrix, in which rows are the number of sample data, and columns are the number of identified elements. Matrix $X$ is factorized in the form of matrix $F$ and $G$, where the $\mathrm{F}$ matrix is the factor profile, and the $\mathrm{G}$ matrix is the source contribution. This factor profile needs to 
be interpreted to identify the types of sources that might contribute to the sample based on previous studies as well as on emission inventory data.

The advantage of Positive Matrix Factorization (PMF) is that results are obtained with the limitation that no sample can result in negative source contributions. Data with values below the method detection limit can still be used with adjustments for uncertainty values so that this data has less influence than data with values above the detection limit.

The PMF model is a calculation using the least-squares method, where an assumption of the number of factors is required to solve Eq 3 . The contribution factor and factor profile come from the PMF model, minimizing the $\mathrm{Q}$ function. The equation is as follows:

$$
Q=\sum_{i=1}^{n} \sum_{j=1}^{m}\left(\frac{X i j-\sum_{k=1}^{p} G i k F k j}{u i j}\right)^{2}
$$

PMF requires two input data sets, which here are species concentration data and uncertainty data, to estimate the contribution factor $(G)$ and factor profile $(F)[16,17]$. The selection of the number of factors can be made from the emission inventory data to determine sources of pollutants. The $Q$ value in $\mathrm{Eq} 3$ is obtained by experimentation using the assumption of several possible numbers of factors (4-8 factors) to obtain an interpretable result. The $Q$ value obtained from the model is the goodness of fit parameter and an estimate of how well the model fits the input data [17-19].

\subsection{Conditional Probability Function}

The locations of the pollutant sources were estimated using the source contributions from the PMF combined with wind directions and wind speed data at the sampling location. The data were analyzed using the CPF method with the help of Microsoft Excel software. The equation used was as follows:

$$
\mathrm{CPF}_{\Delta \theta}=\frac{M_{\Delta \theta}}{n_{\Delta \theta}}
$$

where $\left(\mathrm{M}_{\Delta \theta}\right)$ shows the number of occurrences from the wind direction $(\Delta \theta)$ which have a speed above the threshold of $25 \%$ of the highest observed wind speed and $(n \Delta \theta)$ is the total number of occurrences from the overall wind direction. In this study, sixteen (16) cardinal directions were used, so $(\Delta \theta)$ was set at $22.5^{\circ}$ and only wind speeds $>1 \mathrm{~m} / \mathrm{s}$ were considered. The results of the CPF analysis were formed in a radar plot and then overlaid on a map of the sampling location.

\section{Results And Discussion}

\subsection{Concentrations of $\mathrm{PM}_{2.5}$ and $\mathrm{PM}_{10}$}


The average daily concentrations of $\mathrm{PM}_{2.5}$ and $\mathrm{PM}_{10}$ were $11.47 \mu \mathrm{g} / \mathrm{m}^{3}$ and $27.49 \mu \mathrm{g} / \mathrm{m}^{3}$, or $11.45 \mu \mathrm{g} / \mathrm{Nm}^{3}$ and $26.98 \mu \mathrm{g} / \mathrm{Nm}^{3}$. Research by Ahmad and Santoso [20] stated that the annual concentrations in Surabaya for $\mathrm{PM}_{2.5}$ and $\mathrm{PM}_{10}$ were between $8.53 \mu \mathrm{g} / \mathrm{m}^{3}-26.38 \mu \mathrm{g} / \mathrm{m}^{3}$ and $18.35 \mu \mathrm{g} / \mathrm{m}^{3}-50.65 \mu \mathrm{g} / \mathrm{m}^{3}$, respectively.

The research conducted in Southeast Asia by Khan et al. [21] also stated that $\mathrm{PM}_{2.5}$ concentrations were between $6.64-68.2 \mu \mathrm{g} / \mathrm{m}^{3}$ during the southwest monsoon. Based on Government Regulation Number 41 Year 1999 (GRN41) [22], the daily air quality standard concentrations of $\mathrm{PM}_{2.5}$ and $\mathrm{PM}_{10}$ are $65 \mu \mathrm{g} / \mathrm{Nm}^{3}$ and $150 \mu \mathrm{g} / \mathrm{Nm}^{3}$. According to the World Health Organization (WHO), the daily air quality standard concentrations of $\mathrm{PM}_{2.5}$ and $\mathrm{PM}_{10}$ are $25 \mu \mathrm{g} / \mathrm{m}^{3}$ and $50 \mu \mathrm{g} / \mathrm{m}^{3}$.

The results of this study show that the daily concentrations of $\mathrm{PM}_{2.5}$ and $\mathrm{PM}_{10}$ in West Surabaya meet the quality standards for daily PM concentration based on GRN41 and the WHO. The daily concentrations of $\mathrm{PM}_{2.5}$ and $\mathrm{PM}_{10}$ can be seen in Fig. 3.

From Fig. 3, it can be seen that the daily concentration of $\mathrm{PM}_{2.5}$ was between $3.95 \mu \mathrm{g} / \mathrm{m}^{3}$ and $27.45 \mu \mathrm{g} / \mathrm{m}^{3}$. This met the quality standards of GRN41 and WHO, except on April 6, 2020. At that time, the $\mathrm{PM}_{2.5}$ concentration was $27.45 \mu \mathrm{g} / \mathrm{m}^{3}$, exceeding the WHO daily $\mathrm{PM}_{2.5}$ quality standard. The minimum daily concentration of $\mathrm{PM}_{2.5}$ was $3.95 \mu \mathrm{g} / \mathrm{m}^{3}$, occurring on January 1,2020 . The lowest daily concentration of $\mathrm{PM}_{10}, 9.31 \mu \mathrm{g} / \mathrm{m}^{3}$, also occurred on January 1,2020 . The highest daily concentration of $\mathrm{PM}_{10}$ was $64.82 \mu \mathrm{g} / \mathrm{m}^{3}$ on October 21,2020 , exceeding the WHO quality standard by $65 \mu \mathrm{g} / \mathrm{m}^{3}$.

Increases and decreases in $\mathrm{PM}_{2.5}$ concentrations coincided with increases and decreases in $\mathrm{PM}_{10}$ concentration, as seen in Fig. 4. For example, on November 2, 2019, $\mathrm{PM}_{2.5}$ concentrations increased to $14.22 \mu \mathrm{g} / \mathrm{m}^{3}$ from $9.88 \mu \mathrm{g} / \mathrm{m}^{3}$ the previous week. The concentration of $\mathrm{PM}_{10}$ on that date was $28.05 \mu \mathrm{g} / \mathrm{m}^{3}$, increased from the previous week's value of $24.53 \mu \mathrm{g} / \mathrm{m}^{3}$. The reduction in concentration can be seen on December 8,2019 , when the $\mathrm{PM}_{2.5}$ concentration decreased drastically from $19.15 \mu \mathrm{g} / \mathrm{m}^{3}$ in the previous week from to $9.11 \mu \mathrm{g} / \mathrm{m}^{3}$, while $\mathrm{PM}_{10}$ concentration decreased to $21.83 \mu \mathrm{g} / \mathrm{m}^{3}$ from $43.86 \mu \mathrm{g} / \mathrm{m}^{3}$ in the previous week. The increases and decreases in PM concentrations could have several causes, such as nearby anthropogenic activities and meteorological conditions.

The daily concentration of $\mathrm{PM}_{2.5}$ on April 6, 2020, and the daily concentration of $\mathrm{PM}_{10}$ on October 21, 2019, were higher than at other times. On those dates, the weather at the research location was sunny, especially in October 2019 because this was during the dry season. In addition, the wind speed was also relatively calm, in the range of $0.5-2.1 \mathrm{~m} / \mathrm{s}$, and the wind direction was from the west and northwest, where there are pollutant source activities such as traffic and toll road construction. The high concentrations of $\mathrm{PM}_{2.5}$ and $\mathrm{PM}_{10}$ at that time could result from these activities. At that time, the wind speeds were relatively calm, so the particulates could not disperse, resulting in high concentrations at that 
location. When the wind speed is high, the particulates can spread out so that the concentration decreases.

Additionally, high particulate concentrations are caused by the intensity or duration of sun exposure. According to Cahyadi et al. [23], intense solar radiation causes the concentration of pollutants to increase because the hot and dry environment causes pollutants to be lifted into the air and float there. The length of solar radiation on October 21, 2019, according to the BMKG, was recorded as 8.6 hours, while the average length of irradiation in October 2019 was 9 hours.

Concentrations of $\mathrm{PM}_{2.5}$ and $\mathrm{PM}_{10}$ were lowest on January 1, 2020; the weather that day and the day before was rainy, with $1.5 \mathrm{~mm}$ of rain falling on December 31, 2019, according to data from the Surabaya City BMKG Perak Meteorological Station 1

On January $1,2020, \mathrm{PM}_{2.5}$ and $\mathrm{PM}_{10}$ were at their lowest concentrations compared to other times. On December 31, 2019, and January 1, 2020, the weather was recorded as rainy. Data from the Surabaya City BMKG Perak Meteorological Station 1 recorded that on December 31, 2019, it rained with an intensity of $1.5 \mathrm{~mm}$.

During the wet season, particulate matter can become rained out by precipitation, which may have caused the lower concentrations on January 1,2020. The decreased concentrations could also have been caused by reduced traffic, as it was a holiday. Figure 5 show that the average concentration in OctoberDecember 2019 was higher than in January-March 2020. This is because October-December 2019 was during the dry season, while during January-April 2020 the region had entered the rainy season. During the dry season, evaporation is higher, so the concentration of particulates obtained is higher because there are no water droplets to trap the particulates. Meanwhile, during the rainy season, particulates will be trapped in rainwater droplets and thus their concentration will be lower [20].

According to daily rainfall data from the BMKG Perak Meteorological Station I in Surabaya, from October to December 2019, the rainfall in the City of Surabaya was low, averaging $0 \mathrm{~mm}, 0.6 \mathrm{~mm}$, and $2.5 \mathrm{~mm}$ in October, November, and December respectively. Meanwhile, rainfall amounts during the period of January to April 2020 were higher, namely $8.3 \mathrm{~mm}, 20.0 \mathrm{~mm}, 14.2 \mathrm{~mm}$, and $18.1 \mathrm{~mm}$ for the four months.

The concentrations of $\mathrm{PM}_{2.5}$ and $\mathrm{PM}_{10}$ were influenced by activities around the site. In West Surabaya, there are many vehicles that transport goods from the warehouse area. There are also many modes of public transportation, such as buses and private vehicles. In March 2020, the concentrations of $\mathrm{PM}_{2.5}$ and $\mathrm{PM}_{10}$ decreased due to the Covid-19 pandemic, as some offices and schools carried out Work From Home programs which reduced traffic.

High traffic activity can affect the concentration of $\mathrm{PM}_{2.5}$ and $\mathrm{PM}_{10}$. The concentration of $\mathrm{PM}_{10}$ is highest when traffic is heavy compared to when traffic is moderate or low. In a study in Beijing, $\mathrm{PM}_{2.5}$ concentrations around main roads with traffic and construction activities were found to be quite high, 
namely $62.16 \pm 39.37 \mu \mathrm{g} / \mathrm{m}^{3}[24,25] . \mathrm{PM}_{2.5}$ and $\mathrm{PM}_{10}$ concentrations are also affected by wind direction and wind speed. The dominant wind direction in October-December is relatively stable, from the northeast and west, while in January-February, the wind direction is from the west. In March, the wind comes from the northeast and northwest, while in April, the wind comes from the northwest and southwest. Upwind in these directions from the sampling site, there are various industrial activities, warehousing, road construction, and also quite dense traffic.

In several previous studies, $\mathrm{PM}_{2.5}$ concentrations were found to be higher at industrial sites, and fossil fuels were the main source of PM in Dhaka, Bangladesh [26, 27]. Therefore, the concentrations of $\mathrm{PM}_{2.5}$ and $\mathrm{PM}_{10}$ at the research site could be influenced by the presence of industrial and fuel-burning activities.

\subsection{Multi-element Identification}

Based on XRF analysis, particulate samples taken in West Surabaya in October 2019-April 2020 were shown to contain 18 elements, including metal elements, as seen in Table 2. 
Table 1

Concentration of PM

\begin{tabular}{|c|c|c|c|}
\hline Date & Concentration of $\mathrm{PM}_{2.5}$ & Concentration of $\mathrm{PM}_{10}$ & Concentration of $\mathrm{PM}_{2.5-10}$ \\
\hline 10/15/2019 & 8.38 & 33.58 & 25.20 \\
\hline 10/21/2019 & 18.30 & 64.82 & 46.52 \\
\hline 10/27/2019 & 9.88 & 24.53 & 14.65 \\
\hline $11 / 2 / 2019$ & 14.22 & 28.05 & 13.83 \\
\hline $11 / 8 / 2019$ & 6.18 & 28.71 & 22.53 \\
\hline $11 / 14 / 2019$ & 17.22 & 40.49 & 23.27 \\
\hline 11/20/2019 & 9.31 & 36.07 & 26.75 \\
\hline $11 / 26 / 2019$ & 15.05 & 39.02 & 23.96 \\
\hline $12 / 2 / 2019$ & 19.15 & 43.86 & 24.71 \\
\hline $12 / 8 / 2019$ & 9.11 & 21.83 & 12.72 \\
\hline $12 / 14 / 2019$ & 11.47 & 30.40 & 18.93 \\
\hline $12 / 20 / 2019$ & 16.72 & 30.24 & 13.52 \\
\hline $12 / 26 / 2019$ & 6.51 & 35.25 & 28.74 \\
\hline $12 / 31 / 2019$ & 13.94 & 20.68 & 6.74 \\
\hline $1 / 1 / 2020$ & 3.95 & 9.31 & 5.36 \\
\hline $1 / 7 / 2020$ & 7.61 & 12.85 & 5.24 \\
\hline $1 / 13 / 2020$ & 4.78 & 15.59 & 10.81 \\
\hline $1 / 19 / 2020$ & 19.47 & 28.77 & 9.30 \\
\hline $1 / 25 / 2020$ & 5.98 & 13.76 & 7.78 \\
\hline $1 / 31 / 2020$ & 10.43 & 18.20 & 7.77 \\
\hline $2 / 6 / 2020$ & 5.47 & 16.94 & 11.47 \\
\hline $2 / 12 / 2020$ & 19.63 & 35.63 & 16.00 \\
\hline $2 / 13 / 2020$ & 10.71 & 43.21 & 32.50 \\
\hline $2 / 18 / 2020$ & 9.76 & 14.80 & 5.04 \\
\hline $2 / 24 / 2020$ & 5.76 & 15.12 & 9.36 \\
\hline $3 / 1 / 2020$ & 6.97 & 12.75 & 5.79 \\
\hline
\end{tabular}




\begin{tabular}{|llll|}
\hline Date & Concentration of $\mathrm{PM}_{\mathbf{2 . 5}}$ & Concentration of $\mathrm{PM}_{10}$ & Concentration of $\mathrm{PM}_{\mathbf{2 . 5}-10}$ \\
\hline $3 / 7 / 2020$ & 6.59 & 12.26 & 5.66 \\
\hline $3 / 13 / 2020$ & 19.16 & 32.00 & 12.84 \\
\hline $3 / 19 / 2020$ & 10.38 & 26.67 & 16.29 \\
\hline $3 / 25 / 2020$ & 11.97 & 21.97 & 10.00 \\
\hline $3 / 31 / 2020$ & 5.50 & 35.19 & 29.69 \\
\hline$/ 6 / 2020$ & 27.45 & 37.01 & 9.56 \\
\hline Mean & 11.47 & 27.49 & \\
\hline Min & 3.95 & 9.31 & \\
\hline Max & 27.45 & 64.82 & \\
\hline
\end{tabular}


Table 2

Elements in $\mathrm{PM}_{2.5}$ and $\mathrm{PM}_{2.5-10}$

\begin{tabular}{|c|c|c|c|c|}
\hline \multirow[t]{2}{*}{ Elements } & \multicolumn{2}{|c|}{$\mathrm{PM}_{2.5}\left(\mathrm{ng} / \mathrm{m}^{3}\right)$} & \multicolumn{2}{|c|}{$\mathrm{PM}_{2.5-10}\left(\mathrm{ng} / \mathrm{m}^{3}\right)$} \\
\hline & Mean & Std. Dev. & Mean & Std. Dev. \\
\hline $\mathrm{Na}$ & 165.0 & 93.7 & 237.6 & 130.7 \\
\hline $\mathrm{Mg}$ & 45.0 & 29.0 & 143.2 & 91.4 \\
\hline Al & 47.7 & 59.6 & 259.5 & 201.3 \\
\hline $\mathrm{Si}$ & 153.5 & 138.4 & 719.4 & 524.6 \\
\hline$S$ & 685.5 & 344.0 & 232.5 & 119.7 \\
\hline $\mathrm{Cl}$ & 8.9 & 10.2 & 341.3 & 217.5 \\
\hline K & 144.1 & 82.3 & 128.4 & 80.1 \\
\hline $\mathrm{Ca}$ & 89.1 & 89.5 & 705.9 & 495.8 \\
\hline $\mathrm{Ti}$ & 4.6 & 3.9 & 26.5 & 17.4 \\
\hline V & 0.6 & 0.6 & 1.1 & 0.9 \\
\hline $\mathrm{Cr}$ & 0.4 & 0.4 & 0.8 & 0.7 \\
\hline $\mathrm{Mn}$ & 3.9 & 3.3 & 9.8 & 7.2 \\
\hline $\mathrm{Fe}$ & 90.5 & 71.7 & 432.7 & 298.1 \\
\hline $\mathrm{Ni}$ & 0.5 & 0.4 & 0.5 & 0.5 \\
\hline $\mathrm{Cu}$ & 1.6 & 1.3 & 2.6 & 1.9 \\
\hline $\mathrm{Zn}$ & 63.9 & 82.4 & 82.9 & 100.0 \\
\hline $\mathrm{Br}$ & 3.2 & 3.1 & 3.2 & 2.4 \\
\hline $\mathrm{Pb}$ & 17.0 & 28.0 & 10.7 & 20.3 \\
\hline
\end{tabular}

Based on Table 2, the elements contained in $\mathrm{PM}_{2.5}$ and $\mathrm{PM}_{2.5-10}$ were $\mathrm{Na}, \mathrm{Mg}, \mathrm{Al}, \mathrm{Si}, \mathrm{S}, \mathrm{K}, \mathrm{Cl}, \mathrm{Ca}, \mathrm{Ti}, \mathrm{V}, \mathrm{Cr}$, $\mathrm{Mn}, \mathrm{Fe}, \mathrm{Ni}, \mathrm{Cu}, \mathrm{Zn}, \mathrm{Br}$, and $\mathrm{Pb}$. Measurement of the metal element composition contained in these particulates is an important factor for identifying possible sources of pollutants and can be used for air quality management. The Mn element quality standard defined by WHO is $0.018 \mu \mathrm{g} / \mathrm{m}^{3}$ with a 24-hour measurement, while according to the Ontario Ministry of the Environment Ambient Air Quality Criteria/Texas Commission on Environment Quality (OAQC/TCEQ), the Mn concentration quality standard with a 24-hour measurement is $2.5 \mu \mathrm{g} / \mathrm{m}^{3}$. The average concentrations of the element $\mathrm{Mn}$ in West Surabaya in October 2019-April 2020 were $0.0039 \mu \mathrm{g} / \mathrm{m}^{3}$ and $0.0098 \mu \mathrm{g} / \mathrm{m}^{3}$ for $\mathrm{PM}_{2.5}$ and $\mathrm{PM}_{2.5-10}$. Thus, the airborne Mn in Surabaya in that month met the air quality standards from WHO and 
OAQC/TCEQ. However, the Mn concentration nevertheless needs to be considered because exposure to $\mathrm{Mn}$ can disrupt the nervous system, causing symptoms such as allergies, increased muscle tone, tremors, mental disorders, and death [8].

The average Ni concentrations in the $\mathrm{PM}_{2.5}$ and $\mathrm{PM}_{2.5-10}$ samples were $0.00053 \mu \mathrm{g} / \mathrm{m}^{3}$ and $0.00048 \mu \mathrm{g} / \mathrm{m}^{3}$, while the OAQC/TCEQ quality standard for Ni concentration with a 24-hour measurement is $2 \mu \mathrm{g} / \mathrm{m}^{3}$. The concentration of $\mathrm{Ni}$ found in West Surabaya at the time of the study thus met the quality standards of the OAQC/TCEQ. The presence of metallic elements such as $\mathrm{Ni}$ in these particulates needs to be considered even though these results show that the concentration is low. Ni exposure causes disruption of the endocrine system, and $\mathrm{Ni}$ is known as a carcinogen. In Delhi, India, increased risk of death from cancer was found to be due to exposure to $\mathrm{Ni}[8,9]$.

$\mathrm{Pb}$ was found to have an average concentration of $0.017 \mu \mathrm{g} / \mathrm{m}^{3}$ in the $\mathrm{PM}_{2.5}$ sample and $0.011 \mu \mathrm{g} / \mathrm{m}^{3}$ in the $\mathrm{PM}_{2.5-10}$ sample. In Indonesia, $\mathrm{Pb}$ has been regulated in Government Regulation No. 41 of 1999 with 24-hour measurement quality standards of $2 \mu \mathrm{g} / \mathrm{m}^{3}$. Pb elemental quality standards have also been regulated by other organizations such as OAQC/TCEQ and the United States Environmental Protection Agency (EPA, NA AQS) with quality standards of $2 \mathrm{ug} / \mathrm{m}^{3}$ for OAQC/TCEQ over 24 hours and $0.15 \mathrm{ug} / \mathrm{m}^{3}$ for the United States EPA (NA AQS) over three months. The concentration of Pb in West Surabaya meets the requirements of the OAQC/TCEQ and the United States EPA (NA AQS) quality standards. $\mathrm{Pb}$ is a heavy metal element that needs to be monitored, especially in children, because it has carcinogenic properties. As found in Delhi, India, the risk of death in Pb-exposed children is high because of the presence of $\mathrm{Pb}$ in the blood. This element also plays an important role in myocardial toxicity $[9,10]$.

Figure 6 shows elemental concentrations, listed here in order from highest to lowest concentrations, of $S$, $\mathrm{Na}, \mathrm{Si}, \mathrm{K}, \mathrm{Fe}, \mathrm{Ca}, \mathrm{Zn}, \mathrm{Al}, \mathrm{Mg}, \mathrm{Pb}, \mathrm{Cl}, \mathrm{Ti}, \mathrm{Mn}, \mathrm{Br}, \mathrm{Cu}, \mathrm{V}, \mathrm{Ni}$, and $\mathrm{Cr}$. The element $\mathrm{S}$ has the highest concentration in $\mathrm{PM}_{2.5}$, with an average concentration of $685.5 \mathrm{ng} / \mathrm{m}^{3}$. In addition to $\mathrm{S}$, other elements also have high concentrations in the $\mathrm{PM}_{2.5}$ samples, including $\mathrm{Na}$ and $\mathrm{Si}$, with average concentrations of 165 and $153 \mathrm{ng} / \mathrm{m}^{3}$. The highest S concentration occurred on January 19,2020 , with a value of $1655 \mathrm{ng} / \mathrm{m}^{3}$. At that time, the wind direction was from the west and northwest with an average speed of $0.5-2.1 \mathrm{~m} / \mathrm{s}$. The highest $\mathrm{Na}$ concentration occurred on March 25, 2020, with a concentration of $432.6 \mathrm{ng} / \mathrm{m}^{3}$. On that date, the wind direction originated from the northeast with a speed of $0.5-5.7 \mathrm{~m} / \mathrm{s}$. The highest $\mathrm{Si}$

concentration of $700.1 \mathrm{ng} / \mathrm{m}^{3}$ occurred on October 21,2019 , when the wind speed was relatively calm at $0.5-2.1 \mathrm{~m} / \mathrm{s}$ from the west. The high concentration of sulfur (S) might be caused by vehicles, and the Si may have come from road dust, which is present in the western part of the study site, while the $\mathrm{Na}$ is characteristic of sea salt $[19,20]$. To the northeast and southeast of the study site, the ocean is a potential contributor to the particulate $\mathrm{Na}$ content.

In the $\mathrm{PM}_{2.5-10}$ sample (Fig. $6 \mathrm{~b}$ ), the elements identified from high concentration to low concentration were $\mathrm{Si}, \mathrm{Ca}, \mathrm{Fe}, \mathrm{Cl}, \mathrm{Al}, \mathrm{Na}, \mathrm{S}, \mathrm{Mg}, \mathrm{K}, \mathrm{Zn}, \mathrm{Ti}, \mathrm{Pb}, \mathrm{Mn}, \mathrm{Br}, \mathrm{Cu}, \mathrm{V}, \mathrm{Cr}$, and Ni. The three (3) elements with the highest concentrations were $\mathrm{Si}, \mathrm{Ca}$, and $\mathrm{Fe}$, with average concentrations of $719.4 \mathrm{ng} / \mathrm{m}^{3}, 705.9 \mathrm{ng} / \mathrm{m}^{3}$, 
and $432.67 \mathrm{ng} / \mathrm{m}^{3}$ respectively. Maximum concentrations of these elements occurred on October 21, 2019 , when the wind direction was from the west, with a relatively calm speed of $0.5-2.1 \mathrm{~m} / \mathrm{s}$. Coarse particulate matter also had its highest concentration, $46.52 \mu \mathrm{g} / \mathrm{m}^{3}$, at that time. High concentrations of $\mathrm{Si}, \mathrm{Ca}$, and $\mathrm{Fe}$ could be caused by construction/cement-manufacturing activities, or could result from soil, road dust, or traffic.

To the west of the research location, there are toll roads and toll road construction which could be a potential source of high concentration of $\mathrm{Si}, \mathrm{Ca}$, and $\mathrm{Fe}$ at the study site. Based on the measurements conducted in West Surabaya in October 2019-April 2020, S, Si, Ca, Fe, Cl, and $\mathrm{Na}$ were higher in concentration than the other elements measured. Elements which were identified in ambient air in several cities, such as $\mathrm{Na}, \mathrm{Mg}, \mathrm{Al}, \mathrm{Si}, \mathrm{S}, \mathrm{K}, \mathrm{Ca}, \mathrm{Cr}, \mathrm{Mn}, \mathrm{Fe}, \mathrm{Co}, \mathrm{Ni}, \mathrm{Cu}, \mathrm{Zn}$, and $\mathrm{Pb}$, were previously found in Surabaya, with $\mathrm{Mg}, \mathrm{Si}, \mathrm{Ca}$, and $\mathrm{Zn}$ showing the highest concentrations [13].

Metal elements found in samples of $\mathrm{PM}_{2.5}$ and $\mathrm{PM}_{2.5-10}$ in West Surabaya were $\mathrm{Ti}, \mathrm{V}, \mathrm{Cr}, \mathrm{Mn}, \mathrm{Ni}, \mathrm{Cu}, \mathrm{Br}$, and $\mathrm{Pb}$. This is consistent with the study by Police et al. [28], which states that $\mathrm{PM}_{10}$ found in industrial areas along the coast in Viskhapatnam, India, are characterized by chemical elements such as $\mathrm{Al}, \mathrm{V}, \mathrm{Cr}$, $\mathrm{Mn}, \mathrm{Fe}, \mathrm{Ni}, \mathrm{Cu}, \mathrm{Zn}, \mathrm{As}, \mathrm{Pb}, \mathrm{Cd}, \mathrm{Cl}^{-}, \mathrm{F}^{-}, \mathrm{NO}_{3}{ }^{-}, \mathrm{SO}_{4}{ }^{2-}, \mathrm{Na}^{+}, \mathrm{K}^{+}, \mathrm{Mg}^{2+}$, and $\mathrm{Ca}^{2+}$.

Element identification results in West Surabaya show that several elements are strongly correlated, which can indicate a common source. In $\mathrm{PM}_{2.5}$, Al concentrations have a very strong correlation with $\mathrm{Si}$ concentrations, with an $R^{2}$ value of 0.933 . Al is also strongly correlated with $\mathrm{Ca}$, $\mathrm{Ti}$, and $\mathrm{Fe}$, with $\mathrm{R}^{2}$ values of $0.744,0.735$, and 0.772 . According to Jain et al. [29], Al is a marker of ground dust. Based on observations of the area around the study site, from the northwest to the east and from the southeast to the south there is open space that is used for toll road construction. Ca is also a marker for construction activity. A strong correlation between these elements can indicate that soil and construction are potential pollutant sources. Ca also has a strong correlation in $\mathrm{PM}_{2.5-10}$.

$\mathrm{PM}_{2.5-10}$ also contains $\mathrm{S}$ concentrations that are strongly correlated with $\mathrm{Al}, \mathrm{Si}, \mathrm{K}, \mathrm{Ca}, \mathrm{Ti}, \mathrm{Fe}$, and $\mathrm{Mn}$ concentrations. $\mathrm{S}$ is a marker of vehicular sources, while the strong correlation between $\mathrm{S}$ and other elements, such as $\mathrm{Al}, \mathrm{Si}$, and $\mathrm{Ti}$, indicates a potential source from road dust. The $\mathrm{Zn}$ and $\mathrm{Pb}$ elements in $\mathrm{PM}_{2.5}$ also have a very strong correlation, with an $\mathrm{R}^{2}$ value of 0.855 . According to Mukhtar et al. [13], Surabaya City has the highest concentration of $\mathrm{Zn}$ and $\mathrm{Pb}$ compared to other studied cities.

The results of the CPF show that the concentrations of $\mathrm{Zn}$ and $\mathrm{Pb}$ come from the east and southeast. Observations around the study site indicate that several manufacturing industries have the potential to be sources of pollutants from $\mathrm{Zn}$ and $\mathrm{Pb}$ elements. The correlation between elements can be the basis for the initial prediction of potential sources.

\subsection{Pollutant source identification}

PMF 5.0 was used for identification of the sources of pollutants in $\mathrm{PM}_{2.5}$ and $\mathrm{PM}_{2.5-10}$. The PMF model is a calculation using the least-squares method where an assumption of the number of factors is required 
to solve Eq. 3, so the factor contribution and the factor profile can be known. The data prepared for this method were element concentrations and uncertainty value data. The concentration of each element was derived from XRF analysis. The uncertainty value of each element was calculated from statistical calculations and the calibration of the instrument. One of the advantages of PMF is its ability to handle lost or undetectable concentration values or data under the detection limit. The undetectable concentration in a sample was replaced by the geometric mean of the measured concentration, and the uncertainty value was defined as four times the geometric mean.

The concentration data and uncertainty values were used as PMF inputs. PMF is conducted assuming some factors to obtain optimal and interpretable results. The number of factors to assume was determined by looking at the surrounding conditions at the research location or the emission inventory data [17].

Contributions of factors and factor profiles were derived from the PMF model, minimizing the $Q$ function. The $Q$ value was obtained by conducting using five to eight (5-8) factors. Interpretable results were obtained using eight (8) factors for $\mathrm{PM}_{2.5}$ and seven (7) factors for $\mathrm{PM}_{2.5-10}$. The obtained goodness of fit was described with $\mathrm{R}^{2}$ values of 0.7 and 0.9 for $\mathrm{PM}_{2.5}$ and $\mathrm{PM}_{2.5-10}$, respectively, as seen in Fig. $7 \mathrm{a}$ and Fig. 7b. The $\mathrm{R}^{2}$ value shows a correlation between the observed concentrations of $\mathrm{PM}_{2.5}$ and $\mathrm{PM}_{2.5-10}$ and the predicted concentrations of $\mathrm{PM}_{2.5}$ and $\mathrm{PM}_{2.5-10}$. The two $\mathrm{R}^{2}$ values obtained indicate that the concentration data from $\mathrm{PM}_{2.5}$ and $\mathrm{PM}_{2.5-10}$ have been modeled properly by PMF.

The output of this PMF is a factor profile (F) and source contribution (G). The factor profile needs to be interpreted to determine the potential source of pollutants. Factor profiles are displayed in the bar charts in Fig. 8. The concentrations of each species are indicated by a blue bar graph, and the percent of species for each factor is indicated by a red square. The concentration of the species indicates the concentration of each species in a particular factor. The percent of the species value is used to determine the potential source of contaminants. For example, the identification of potential sources of $\mathrm{Pb}$ in $\mathrm{PM}_{2.5}$ showed that $57 \%$ of the $\mathrm{Pb}$ was found in Factor 8. In identifying the source of $\mathrm{PM}_{2.5-10}$ pollution in Factor 4, almost $70 \%$ of $\mathrm{Zn}$ was found to be contributed by this factor, while about $50 \%$ of $\mathrm{Na}$ and $\mathrm{Cl}$ were contributed by Factor 7. The source contributions are illustrated in a pie chart showing the percent distribution of source contributions per factor for the total mass of $\mathrm{PM}_{2.5}$ and $\mathrm{PM}_{2.5-10}$. The contribution of this resource is used to determine how much each source contributes to the sample. The value of the source contribution to each subsequent factor is used as one of its data points to simulate the location of potential sources of pollutants using CPF. In this study, only 32 samples were obtained, so the results of the PMF analysis in this study from potential sources of pollutants in West Surabaya remain preliminary.

In $\mathrm{PM}_{2.5}$, eight (8) factors representing potential sources of contaminants were identified (Fig. 8a). The first factor is a mixture of industrial activities using $\mathrm{Cu}$ and biomass combustion, characterized by the elements $\mathrm{Cu}, \mathrm{Mg}$, and $\mathrm{K}$, while $\mathrm{K}$ also indicates biomass burning. Observations around the site show that there are charcoal- and garbage-burning industries nearby which may be contributors to this factor. 
Research by Santoso et al. [19] states that biomass burning produces emissions containing $\mathrm{K}$ in the air around industrial areas. This factor contributed $24.1 \%$ to $\mathrm{PM}_{2.5}$ (Fig. 9a).

The second factor, contributing $11.4 \%$ of $\mathrm{PM}_{2.5}$, is identified as deriving from the metal industries that use $\mathrm{Ni}$ due to the high contribution of $\mathrm{Ni}$ in this factor. $\mathrm{Ni}$ is widely used in the metal industry as a component of steelmaking materials, as well as in the battery industry. Around the study site, there are similar industries that are possible contributors to this factor.

The third factor may come from the non-ferrous metal industry as well as from vehicular tire wire, due to the high $\mathrm{Zn}$ concentration. The contribution of this source to $\mathrm{PM}_{2.5}$ amounted to $2.2 \%$, supported by Ahmad and Santoso [20] research which suggested that the $\mathrm{Zn}$ industry in Surabaya contributed $2 \%$ of the $\mathrm{PM}_{2.5}$ in the area.

The fourth factor, with a contribution of $33 \%$ to $\mathrm{PM}_{2.5}$, was characterized by high amounts of $\mathrm{S}$ and $\mathrm{Na}$. Airborne $\mathrm{S}$ is produced by the conversion of $\mathrm{SO}_{2}$ into sulfate through a homogeneous process, with $\mathrm{SO}_{2}$ provided by diesel vehicle emissions [30,31]. Diesel vehicles are widely used in industrial activities and warehousing activities to transport goods.

The fifth factor was characterized by the elements $\mathrm{Mn}, \mathrm{Fe}$, and $\mathrm{Zn}$. Mn is commonly used in the steel industry, in the production of dry battery cells, and in the production of potassium permanganate. This factor contributed $14.4 \%$ to $\mathrm{PM}_{2.5}$. Around the site, there are iron and steel industries that have the potential to contribute to this factor.

The sixth factor is likely to derive from construction activities because it has a high concentration of Ca. Various construction activities have been identified around the site, such as road construction and other construction industries. This factor contributed $7.9 \%$ to $\mathrm{PM}_{2.5}$

The seventh factor is characterized by high concentrations of $\mathrm{Al}, \mathrm{Si}$, and $\mathrm{V}$, possibly derived from soil dust, burning petroleum, or emissions from ships. This factor contributed $3.2 \%$ to $\mathrm{PM}_{2.5}$. These elements act as markers for sources of soil dust; previous research has suggested that the marker elements of soil dust are $\mathrm{Al}, \mathrm{Si}$, and $\mathrm{Ca}$, in addition to $\mathrm{Fe}, \mathrm{Ti}$, and $\mathrm{Mn}$. The concentrations of these elements tend to be high during the dry season compared to during the rainy season [19, 32]. According to one study Pandolfi et al., [33], existing emissions from ships in urban areas produce anthropogenic air pollution indicated by the elements $\mathrm{V}, \mathrm{Ni}, \mathrm{La}$, and Ce.

The eighth factor is possibly from the lead industry as well as from vehicles because it has a high $\mathrm{Pb}$ concentration. Emissions of $\mathrm{Pb}$ can also come from burning coal or from industries that use coal as fuel. The contribution of this factor to $\mathrm{PM}_{2.5}$ was $3.6 \%$.

In $\mathrm{PM}_{2.5-10}$, the analysis identified seven factors (Fig. 8b). The first factor may come from construction activities because it has high concentrations of $\mathrm{Ca}$ and $\mathrm{Mg}$. $\mathrm{Ca}$ is a marker of construction activities [19, 29]. In research conducted in Southeast Asia by Khan et al. [21], $\mathrm{Mg}$ and $\mathrm{Ca}$ are considered to be marker 
elements of mineral dust, and contribute $28.8 \%$ (Fig. 9b). From observations at the research site, several construction industries, road construction projects, and road repairs have the potential to be a source of pollutants in West Surabaya, especially for Ca.

The second factor, with a contribution of $32 \%$, was characterized by the elements $\mathrm{V}$, Al, and Si, possibly from soil dust and port activity. According to Mukhtar et al. [13], Al can come from new land clearing activities. Construction of toll roads is a possible source of pollutants around the research site.

The third factor contributed 3.8\%, as indicated by S content. Sulfur is a marker element for transportation, deriving from vehicle emissions and diesel fuel used both for land transportation and ship fuel.

The fourth factor, characterized by $\mathrm{Zn}$ and $\mathrm{Pb}$, may derive from the non-ferrous metal industry and contributes $3.7 \%$ of $\mathrm{PM}_{2.5-10}$. The high concentration of $\mathrm{Zn}$ and $\mathrm{Pb}$ at the research site could be due to the steel and warehousing industries that store coal sand. This is supported by research Dai et al., [34] which found that the $\mathrm{Pb}$ and $\mathrm{Zn}$ in $\mathrm{PM}$ come from iron and steel industry activities. Aside from industry, $\mathrm{Zn}$ and $\mathrm{Pb}$ can also be contributed by coal-burning [35].

The fifth factor is possibly derived from the metal industry as well as other industries that use $\mathrm{Cu}$, as indicated because it contains $\mathrm{Ni}$ and $\mathrm{Cu}$; this fifth factor contributes about 7\% to $\mathrm{PM}_{2.5-10}$. Around the research site, there are iron and steel industries and a cable manufacturing industry that may contribute to this factor.

The sixth factor, contributing $14 \%$, may derive from road dust because it is characterized by $\mathrm{Br}$. This road dust comes from a mixture of traffic activity and soil dust; $\mathrm{Br}$ serves as a marker element of road activity $[3,19,29,36-38]$

The seventh factor derives from sea salt because it is characterized by the elements $\mathrm{Na}$ and $\mathrm{Cl}$, with a contribution of $10 \%$. Na and $\mathrm{Cl}$ are marker elements of sea salt; as described in Mukhtar et al. [7], the presence of $\mathrm{Na}$ elements indicates a mixture of other sources of emissions, namely emissions from sea salt, and Santoso et al., [19] argues that the aerosolization of $\mathrm{Na}$ usually coincides with that of $\mathrm{Cl}$. The research site is only about $1 \mathrm{~km}$ from the sea, which may drive variability of $\mathrm{Na}$ in ambient air. Additionally, there are salt ponds in West Surabaya which may contribute the elements $\mathrm{Na}, \mathrm{Cl}$, and $\mathrm{Mg}$, in addition to the marine source.

\subsection{Estimated locations of pollutant sources}

Estimating the locations of the pollutant sources is carried out by the CPF method, which combines the value of the source contribution of each result factor from the PMF with the wind speed and wind direction data at the time of sampling. Only data with winds speeds of $1 \mathrm{~m} / \mathrm{s}$ or greater and at least a $25 \%$ contribution by the source with the highest value are used for the analysis. Eq. 4 gives the calculation method for CPF. 
$\mathrm{PM}_{2.5}$ Factor 1 is characterized by $\mathrm{Cu}, \mathrm{Mg}$, and $\mathrm{K}$, and may derive from industrial activities using $\mathrm{Cu}$ and biomass combustion. Figure 10a shows an estimate of the location of sources for Factor 1. Based on wind direction, the largest concentrations of these elements come from the southeast and northnorthwest, and industries in both directions have the potential to be contributors to this factor. In the north-northwest to the northeast, there are residential areas, while in the south-east there is a wood charcoal industry at a distance of $1 \mathrm{~km}$ and wood processing at a distance of $2 \mathrm{~km}$ from the study site. The wood charcoal manufacturing industry around this research site processes wood waste into wood charcoal. Emissions containing $\mathrm{K}$ are produced from the burning of biomass (smoke), which is the result of an imperfect open combustion process such as burning garbage, forest fires, or cigarette smoke.

The identification of potential sources of pollutants in Factor 2, characterized by its $\mathrm{Ni}$ content, suggests that these may have come from the east, south, and southeast (Fig. 10b). From these directions, several metal industries such as the iron industry are potential contributors to this factor.

The estimated source location of Factor 3, derived from Zn, comes from the east and south-east (Fig. 10c). $\mathrm{Zn}$ is produced from galvanized metal industries, two-stroke engines, and household waste combustion. The potential sources of $\mathrm{Zn}$ pollutants may be derived from nearby industry as well as from vehicular tire wear. At this site, observations show heavy traffic and several likely source industries.

Factor 4, which may come from diesel-fueled vehicles as it is characterized by $\mathrm{S}$, is estimated to come from the east and southeast (Fig. 10d). In those directions, there is heavy traffic on Jalan Tambak Osowilangun because it is a connecting road between Surabaya and Gresik Regency, and many vehicles travel to the warehousing area as well as to Teluk Lamong Port. Tambak Osowilangun Street is heavily traveled by public transportation such as buses and city transport as well as freight trucks. This road is very congested in the morning and evening, caused by many city modes of transport that stop at Jalan Tambak Osowilangun to wait for passengers. Based on daily traffic data from (LHR) Surabaya Year 2012, the daily number of vehicles passing through Osowilangun Road is 41,369 , including motorcycles, cars, city transports, minibuses, pickup trucks, mini trucks, large buses, 2-axis trucks, 3-axis trucks, trailer trucks, and trailers. Emissions from these vehicles can contribute to the high $\mathrm{S}$ concentration in West Surabaya.

The estimated locations of potential sources of pollutants in Factor 5 are to the northeast, southwest, and southeast (Fig. 10e). The fifth factor is characterized by the elements $\mathrm{Mn}, \mathrm{Fe}$, and $\mathrm{Zn}$. Mn is commonly used in the steel industry, the production of dry battery cells, and the production of potassium permanganate; several industries in the area produce goods from steel that may be contributors to this factor.

Meanwhile, the estimated locations of potential sources of pollutants contributing to Factor 6 , marked by their $\mathrm{Ca}$ contents, come from the northeast and the southeast (Fig. 10f). From the observations at the study site, construction of toll roads, road repairs, and a construction industry $1-2 \mathrm{~km}$ away in those directions are potential contributors to this factor. 
The seventh factor, characterized by the elements $\mathrm{Al}, \mathrm{Si}$, and Ti, possibly from soil dust, is estimated to come from the east and southeast (Fig. 10g). Open vacant land located in these directions relative to the study site can potentially be a source of these pollutants.

The estimated source locations for the Pb-rich Factor 8 lie in the southeast and northeast (Fig. 10h). Glass industry in the area is a potential source of pollutants for this factor. The glass industry usually is characterized by emissions of $\mathrm{Pb}, \mathrm{As}$, and $\mathrm{Sb}$, but this remains to be confirmed in Surabaya using other methods to measure these elements.

The estimated locations of the source of pollutants in the first factor of $\mathrm{PM}_{2.5-10}$, possibly deriving from construction as this factor is characterized by $\mathrm{Ca}$, lie to the east and southeast of the study site (Fig. 11a). Observations around the site show that there is a construction industry as well as road construction about $2 \mathrm{~km}$ away, which are potential sources of pollutants for this factor.

The second factor is estimated to come from the southeast (Fig. 11b), where open vacant land about $1 \mathrm{~km}$ away could contribute soil dust as the source of pollutants for this factor.

The third factor, characterized by the elements $\mathrm{S}$ and $\mathrm{Na}$, comes from the northwest to the north and from the southeast (Fig. 11C). It may derive from burning coal. In those directions, some industries may use coal as fuel, such as hydropower and the iron and steel industries.

The fourth factor is characterized by the elements $\mathrm{Zn}$ and $\mathrm{Pb}$. It was estimated to come from the northnorthwest, north-northeast and, south-southeast (Fig. 11d). To the southeast of the study site, there are several non-ferrous metal industries within a distance of $0.5-3 \mathrm{~km}$. The high concentrations of $\mathrm{Zn}$ and $\mathrm{Pb}$ in Surabaya are supported by the results of Ahmad and Santoso [20], which found the highest concentrations of $\mathrm{Zn}$ and $\mathrm{Pb}$ elements in Surabaya compared to other cities and suggested the steel smelting industry as a source of air pollution emissions in Surabaya.

The fifth factor, characterized by the elements $\mathrm{Ni}$ and $\mathrm{Cu}$, is estimated to originate from the northeast and southwest directions (Fig. 11e). Potential sources of pollutants for this factor may be metal industries, including iron, originating from the southwest, but this needs to be further ascertained.

The sixth factor, characterized by the element $\mathrm{Br}$, is estimated to originate to the southeast of the study site (Fig. 11f) and is possibly derived from road dust. A warehousing area with many freight transporters to the southeast of the site can be a contributor to this factor.

The seventh factor, characterized by $\mathrm{Na}$ and $\mathrm{Cl}$ and possibly derived from sea salt, likely has potential sources in the south and southeast (Fig. 11g), where there are salt industries and a salt pond in the south. Large salt ponds and the salt processing industry lie within a distance of about 1-2 km from the study site. The salt processing industry is $2 \mathrm{~km}$ southeast of the research site, while salt ponds are located to the west and south at a distance of $1 \mathrm{~km}$ from the research site. Surabaya has 623 ha of salt farmland, which is processed by salt farmers by draining seawater into swaths of soil to further expedite the 
evaporation process [39]. The salt processing in salt ponds, as well as the salt processing industry in West Surabaya, can be a contributor to the high concentrations of $\mathrm{Na}, \mathrm{Cl}$, and $\mathrm{Mg}$ in West Surabaya.

\section{Conclusions}

The average daily concentrations of $\mathrm{PM}_{2.5}$ and $\mathrm{PM}_{10}$ at the research site were $11.47 \mu \mathrm{g} / \mathrm{m}^{3}$ and $27.49 \mu \mathrm{g} / \mathrm{m}^{3}$, or $11.45 \mu \mathrm{g} / \mathrm{Nm}^{3}$ and $26.98 \mu \mathrm{g} / \mathrm{Nm}^{3}$. The concentration range of $\mathrm{PM}_{2.5}$ is between $3.95 \mu \mathrm{g} / \mathrm{m}^{3}$ and $27.45 \mu \mathrm{g} / \mathrm{m}^{3}$, while the concentrations of $\mathrm{PM}_{10}$ fall between $9.31 \mu \mathrm{g} / \mathrm{m}^{3}$ and $64.82 \mu \mathrm{g} / \mathrm{m}^{3}$. The observed concentrations meet the quality standards of daily PM based on PP No. 41 of 1999 and the WHO. The XRF analysis of PM in West Surabaya identified 18 elements, consisting of $\mathrm{Na}$, $\mathrm{Mg}, \mathrm{Al}, \mathrm{Si}, \mathrm{S}, \mathrm{K}, \mathrm{Cl}, \mathrm{Ca}, \mathrm{Ti}, \mathrm{V}, \mathrm{Cr}, \mathrm{Mn}, \mathrm{Fe}, \mathrm{Ni}, \mathrm{Cu}, \mathrm{Zn}, \mathrm{Br}$, and $\mathrm{Pb}$.

Based on the concentrations of the metal elements, eight (8) and seven (7) factors are obtained, which represent potential sources of pollutants contributing to $\mathrm{PM}_{2.5}$ and $\mathrm{PM}_{2.5-10}$, respectively. For $\mathrm{PM}_{2.5}$, potential sources of pollutants include a mixture of $\mathrm{Cu}$ industry and biomass combustion, $\mathrm{Ni}$ industry, non-ferrous metal industry, transportation, iron and steel industry, construction, soil, port dust, and $\mathrm{Pb}$ industry. For $\mathrm{PM}_{2.5-10}$, potential sources of pollutants include construction, soil dust, transportation, nonferrous metal industry, $\mathrm{Ni}$ industry, port industry, $\mathrm{Br}$ industry, salt, and the sea salt processing industry.

The estimated source locations for pollutants in $\mathrm{PM}_{2.5}$ and $\mathrm{PM}_{2.5-10}$ show that the potential sources of pollutants include port activity, soil dust, transportation, biomass burning, construction, sea salt, and industry from the north and west.

\section{Declarations}

\section{Availability of data and materials}

All data generated or analysed during this study are included in this published article

\section{Competing interests}

The authors declare that they have no competing interests

\section{Funding}

Appreciation and gratitude arealso extended to the Directorate of Research and Community Service, Directorate General of Research and Development, Ministry of Research, Technology and Higher Education of the Republic of Indonesia for providing project funds. This research is part of the Project under the contract: Nomor : 1162/PKS/ITS/2020. A thank you is also for the Center of Nuclear Technology for Materials and Radiometry, BATAN, Bandung, which provided help in supervising the research, and in particular sample preparation and data analysis. 


\section{Authors' contributions}

TNC collecting samples in field, ADS generate idea, present the concepts, supervise research, MS Team member provides facilities for sampling measurement, JH, RB, and AFA give advice and guidance of the research. All authors read and approved the final manuscript

\section{Acknowledgement}

The author would like to thank the Department of Environmental Engineering, Faculty of Civil, Environmental and Geo Engineering, Institut Teknologi Sepuluh Nopember (ITS) for the support and encouragement of this research. We want to thank Center of Nuclear Technology for Materials and Radiometry, BATAN, Bandung for helped sample preparation and analysis data of this study

\section{References}

1. Robinson MS, Zhao M, Zack L, Brindley C, Portz L, Quarterman M, Long X, Herckes P. Characterization of $\mathrm{PM}_{5}$ Collected During Broadcast and Slash-Pile Prescribed Burns of Predominately Ponderosa Pine Forests in Northern Arizona. Atmospheric Environment. 2011; https://doi.org/10.1016/j.atmosenv.2011.01.051

2. Kim KH, Kabir E, Kabir S. A Review on the Human Health Impact of Airborne Particulate Matter. Environment International. 2015; https://doi.org/10.1016/j.envint.2014.10.005

3. Santoso M, Lestiani DD, Mukhtar R, Hamonangan E, Syafrul H, Markwitz A, Hopke PK. Preliminary Study of the Sources of Ambient Air Pollution in Serpong, Indonesia. Atmospheric Pollution Research. 2011; https://doi.org/10.5094/APR.2011.024

4. Yongming H, Peixuan D, Junji C, Posmentier E. Multivariate Analysis of Heavy Metal Contamination in Urban Dusts of Xi'an, Central China. Science of The Total Environment. 2006; https://doi.org/10.1016/j.scitotenv.2005.02.026

5. Mukhtar R., Esron H, Hari W, Muhayatun S, Syukria K. Komponen Kimia $\mathrm{PM}_{2,5}$ dan $\mathrm{PM}_{10}$ di Udara Ambien di Serpong-Tangerang. Ecolab. 2013; 7: 1-48

6. Samet JM, Dominici F, Curriero FC. Fine Particulate Air Pollution and Mortality in 20 U.S. Cities, 19871994. The New England Journal of Medicine. 2000; 343:24

7. Mukhtar R, Lahtiani S, Hamonangan E, Wahyudi H, Santoso M, Lestiani DD. Kajian Baku Mutu Logam Berat di Udara Ambien Sebagai Bahan Masukan Lampiran PP 41/1999 tentang Pengendalian Pencemaran Udara, Ecolab. 2014; 1:8

8. World Health Organization. 2007. Health Risks of Heavy Metals from Longrange Transboundary Air Pollution, Joint WHO Convention Task Force on the Health Aspects of AirPollution

9. Khillare PS, Sarkar S. 2012. Airborne inhalable metals in residential areas of Delhi, India: distribution, source apportionment and health risks. Atmospheric Pollution Research. 2012; https://doi.org/10.5094/APR.2012.004 
10. Zhang Y, Ji X, Ku T, Li G, Sang N. Heavy metals bound to fine particulate matter from northern China induce season-dependent health risks: A study based on myocardial toxicity. Environmental Pollution. 2016; https://doi.org/10.1016/j.envpol.2016.05.072

11. Liu K, Shang Q, Wan C, Song P, Ma C, Cao L. Characteristics and Sources of Heavy Metals in $P_{5}$ during a Typical Haze Episode in Rural and Urban Areas in Taiyuan, China. Atmosphere. 2017; https://doi.org/10.3390/atmos9010002

12. Chen $P, B i X$, Zhang J, Wu J, Feng Y. Assessment of heavy metal pollution characteristics and human health risk of exposure to ambient $\mathrm{PM}_{5}$ in Tianjin, China. Particuology. 2015; https://doi.org/10.1016/j.partic.2014.04.020

13. Mukhtar R, Wahyudi H, Hamonangan PE, Lahtiani S, Santoso M, Dwiana LD, Kurniawati, S. Kandungan Logam Berat dalam Udara Ambien pada Beberapa Kota di Indonesia. Ecolab. 2013; https://doi.org/10.20886/jklh.2013.7.2.49-59

14. Hopke, K., 2000. A Guide to Positive Matrix Factorization, in workshop on UNMIX and PMF as applied to $\mathrm{PM}_{2.5}$. Amsterdam (NL): Willis, Elsevier Press

15. Santoso M, Lestiani DD. Application of ED XRF in Supporting National Program of Air Quality Improvement in Indonesia, XRF Newsletter. 2014; 26

16. Rixson L, Riani E, Santoso M. Karakterisasi Paparan Long Term Particulate Matter di Puspiptek Serpong-Kota Tangerang Selatan. Jurnal IImiah Aplikasi Isotop dan Radiasi. 2015; https://doi.org/10.17146/jair.2015.11.1.2703

17. Wang F, Zhang Z, Acciai C, Zhong Z, Huang Z, Lonati G. An Integrated Method for Factor Number Selection of PMF Model: Case Study on Source Apportionment of Ambient Volatile Organic Compounds in Wuhan. Atmosphere. 2018; https://doi.org/10.3390/atmos9100390

18. Reff A, Eberly SI, Bhave PV. Receptor Modeling of Ambient Particulate Matter Data Using Positive Matrix Factorization: Review of Existing Methods. Journal of the Air \& Waste Management Association. 2007; https://doi.org/10.1080/10473289.2007.10465319

19. Santoso M, Hopke PK, Hidayat A, Diah DL. Sources Identification of the Atmospheric Aerosol at Urban and Suburban Sites in Indonesia by Positive Matrix Factorization. Science of Total Environment. 2008; https://doi.org/10.1016/j.scitotenv.2008.01.057

20. Ahmad EF, Santoso M. 2016. Analisis karakterisasi Konsentrasi dan Komposisi Partikulat Udara (Studi case: Surabaya). Jurnal Kimia Valensi: Jurnal Penelitian dan Pengembangan Ilmu Kimia. 2018; 2:2; 97-103

21. Khan MF, Sulong NA, Latif MT, Nadzir MSM, Amil N, Hussain DFM, Lee V, Hosaini, PN, Shaharom S, Yusoff NAYM, Hoque HMS, Chung JX, Sahani M, Mohd Tahir N, Juneng L, Maulud KNA, Abdullah SMS, Fujii Y, Tohno S, Mizohata A. Comprehensive assessment of $\mathrm{PM}_{5}$ physicochemical properties during the Southeast Asia dry season (southwest monsoon): Aerosol Load in Tropical Monsoon Season. Journal of Geophysical Research: Atmosphere. 2016; https://doi.org/10.1002/2016JD025894

22. Government Regulation Number 41.1999. Air Pollution Control 
23. Cahyadi W, Achmad B, Suhartono E, Razie F. Pengaruh Faktor Meteorologis dan Konsentrasi Partikulat $\left(\mathrm{PM}_{10}\right)$ Terhadap Kejadian ISPA (Studi Kasus Kecamatan Banjarbaru Selatan, Kota Banjarbaru Tahun 2014-2015). EnviroScienteae. 2016; 12:3; 301-311

24. Elhadi R, Abdullah AM, Abdullah AH, Hanan Ash'aari Z, Kura NU., Gumel DY, Adamu A. Source Identification of Heavy Metals in Particulate Matter $\left(\mathrm{PM}_{10}\right)$ in a Malaysian Traffic Area Using Multivariate Techniques. Polish Journal of Environmental Studies. 2017; https://doi.org/10.15244/pjoes/6994

25. Gao J, Peng X, Chen G, Xu J, Shi GL, Zhang YC, Feng YC. Insights into the chemical characterization and sources of $\mathrm{PM}_{5}$ in Beijing at a 1-h time resolution. Science of The Total Environment. 2016; https://doi.org/10.1016/j.scitotenv.2015.10.082

26. Merétei T, Bite PZ, Báthory C, Bolla Z. Particulate Matter and Heavy Metal Air Pollution in the Middle East Region. Material Science and Engineering. 2017; 42:1;86-93

27. Salam A, Hossain T, Siddique MNA, Alam AMS. Characteristics of atmospheric trace gases, particulate matter, and heavy metal pollution in Dhaka, Bangladesh. Air Quality, Atmosphere, and Health. 2008; https://doi.org/10.1007/s11869-008-0017-8

28. Police S, Sahu SK, Pandit GG. Chemical characterization of atmospheric particulate matter and their source apportionment at an emerging industrial coastal city, Visakhapatnam, India, Atmospheric Pollution Research. 2016; https://doi.org/10.1016/j.apr.2016.03.007

29. Jain S, Sharma SK, Mandal TK, Saxena M. Source apportionment of $P M_{10}$ in Delhi, India using PCA/APCS, UNMIX and PMF. Particuology. 2018; https://doi.org/10.1016/j.partic.2017.05.009

30. Chueinta W, Hopke PK, Paatero P. Investigation of Sources Atmospheric Aerosol at Urban and Suburban Residential Areas in Thailand by Positive Matrix Factorization. Atmospheric Environment. 2000; 34; 3319-3329

31. Begum BA, Eugene K, Biswas, SK, Hopke PK. Investigation of Sources of Atmospheric Aerosol at Urban and Semi-Urban Areas in Bangladesh. Atmospheric Environment. 2004; 38; 3025-3038

32. Lestiani DD, Santoso M, Kurniawati S, Markwitz A. Characteristic of Airborne Particulate Matter Samples Collected From two semi-industrial sites in Bandung, Indonesia. Indonesian Journal of Chemistry. 2013; https://doi.org/10.22146/ijc.21287

33. Pandolfi M, Gonzalez-Castanedo Y, Alastuey A, de la Rosa JD, Mantilla E, de la Campa AS, Querol X, Pey J, Amato F, Moreno T. Source apportionment of $\mathrm{PM}_{10}$ and $\mathrm{PM}_{5}$ at multiple sites in the strait of Gibraltar by PMF: impact of shipping emissions. Environmental Science and Pollution Research. 2011; https://doi.org/10.1007/s11356-010-0373-4

34. Dai QL, Xiao HB, Jian HW, Jian HW, Jian HW, Yu FZ, Jing W, Hong X, Lin Y, Li J, Yin CF. Characterization and Source Identification of Heavy Metals in Ambient $\mathrm{PM}_{10}$ and $\mathrm{PM}_{5}$ in an Integrated Iron and Steel Industry Zone Compared with a Background Site, Aerosol and Air Quality Research. 2015; 15; 875-887 
35. Gao J, Peng X, Chen G, Xu J, Shi GL, Zhang YC, Feng YC. Insights into the chemical characterization and sources of $\mathrm{PM}_{5}$ in Beijing at a 1-h time resolution. Science of The Total Environment. 2016; https://doi.org/10.1016/j.scitotenv.2015.10.082

36. Banerjee T, Murari V, Kumar M, Raju MP. Source apportionment of airborne particulates through receptor modeling: Indian scenario. Atmospheric Research. 2015; https://doi.org/10.1016/j.atmosres.2015.04.017

37. Du L, Wang Y, Wu Z, Hou C, Mao H, Li T, Nie X. PM ${ }_{5}$-Bound Toxic Elements in an Urban City in East China: Concentrations, Sources, and Health Risks. International Journal of Environment Research and Public Health. 2019; https://doi.org/10.3390/ijerph16010164

38. Alam K, Mukhtar A, Shahid I, Blaschke T, Majid H, Rahman S, Khan R, Rahman N. Source Apportionment and Characterization of Particulate Matter $\left(\mathrm{PM}_{10}\right)$ in Urban Environment of Lahore. Aerosol Air Quality Research. 2014; https://doi.org/10.4209/aaqr.2014.01.0005

39. Mahdi IF and Soemardiono B. Kompleks Pengembangan Garam Terpadu Surabaya. Jurnal Sains dan Seni ITS. 2018; 7:2

\section{Figures}

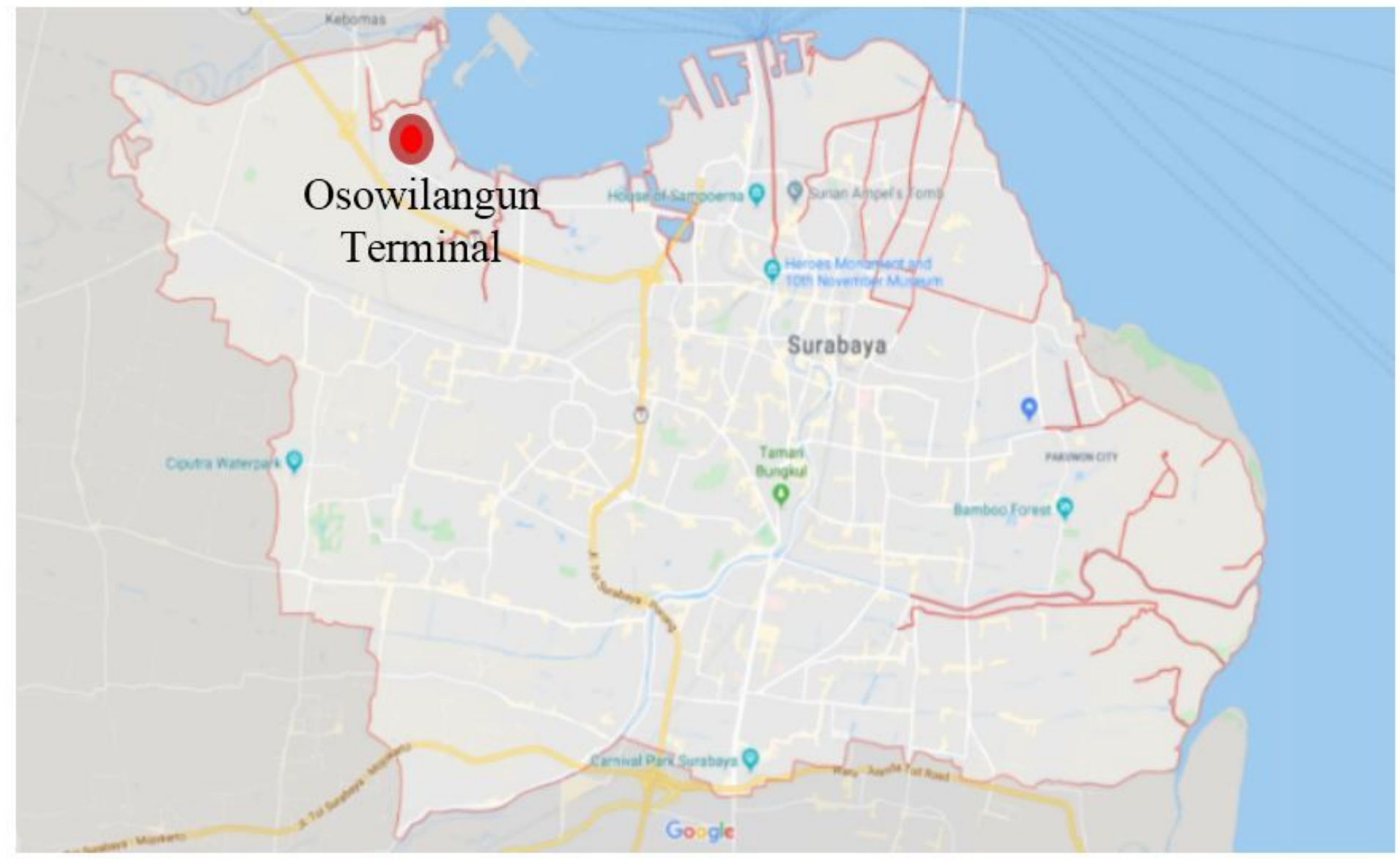

\section{Figure 1}


Site Location

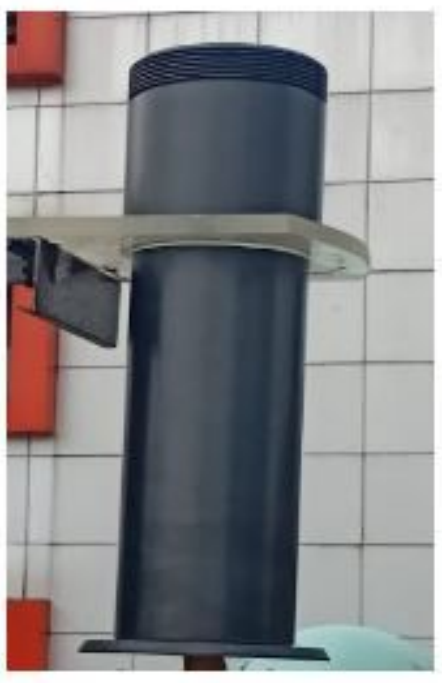

a



d

b
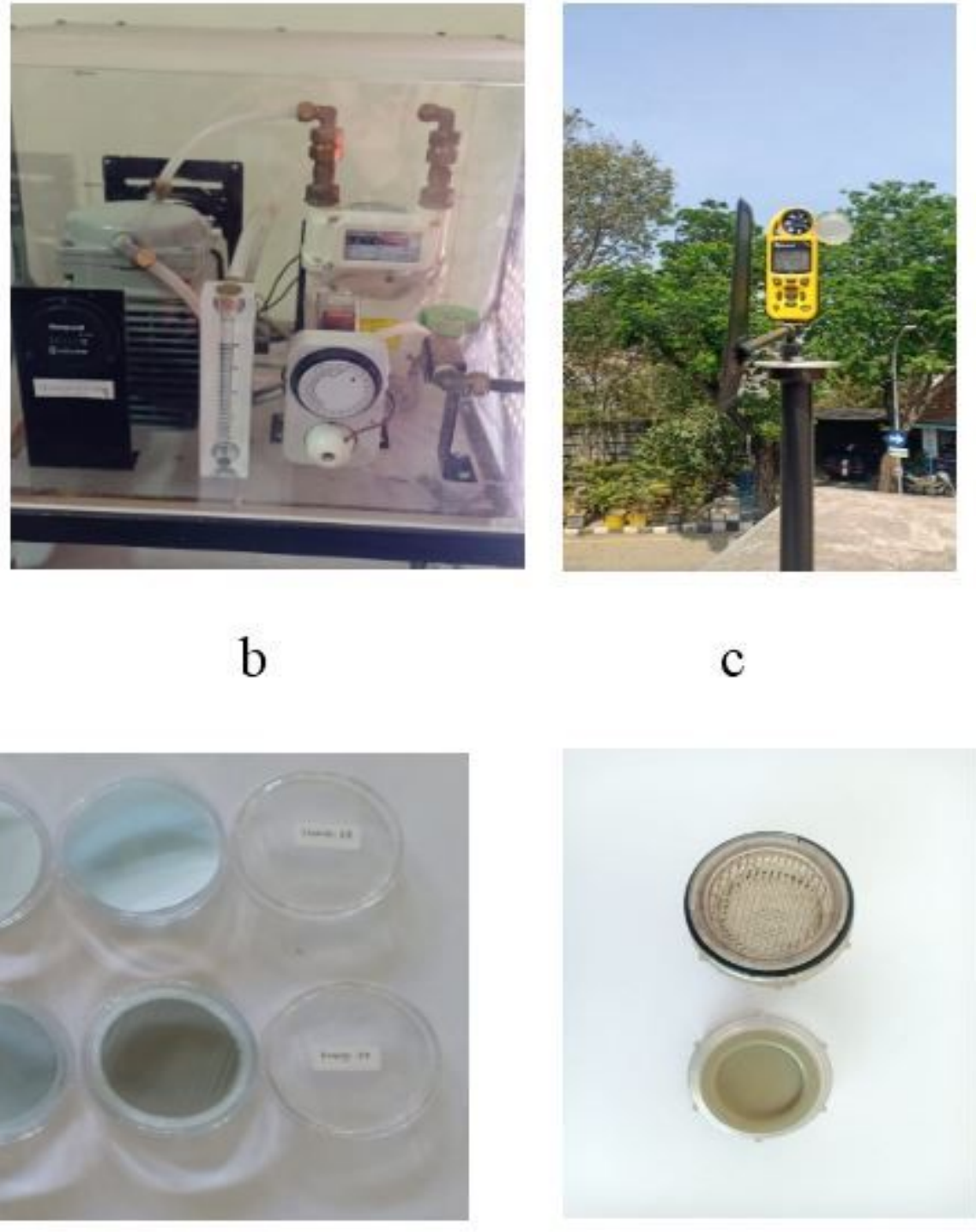

e

\section{Figure 2}

(a) Container, (b) flow meter, (c) Kestrel, (d) filters, and (e) cassette filter

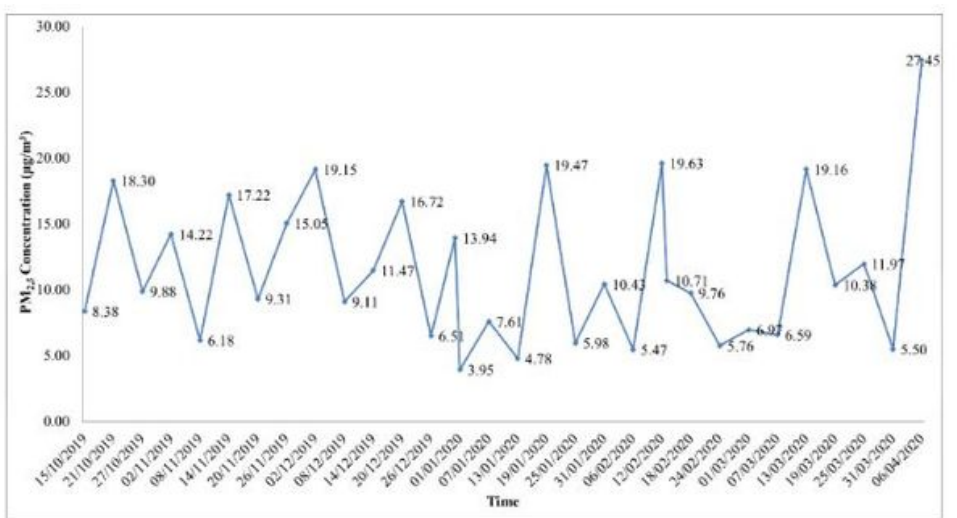

a

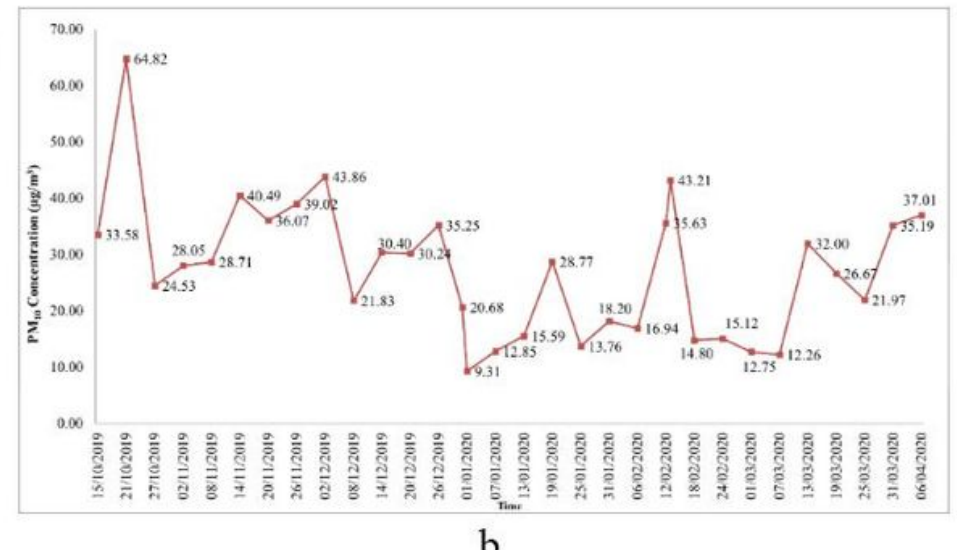

$\mathrm{b}$ 
Figure 3

(a) Daily Concentration of PM2.5 (b) Daily Concentration of PM10

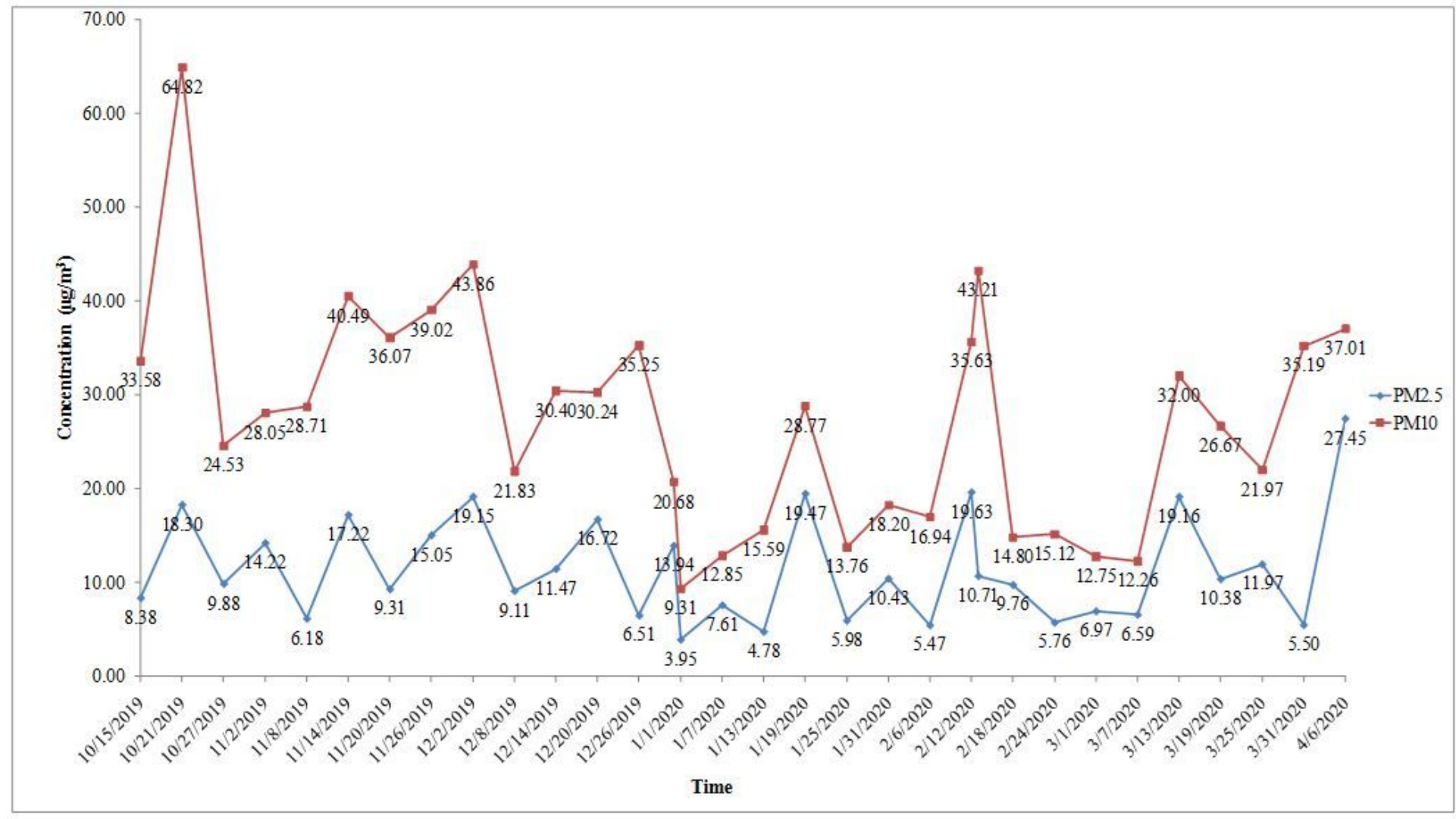

Figure 4

Concentrations of PM2.5 and PM10



a

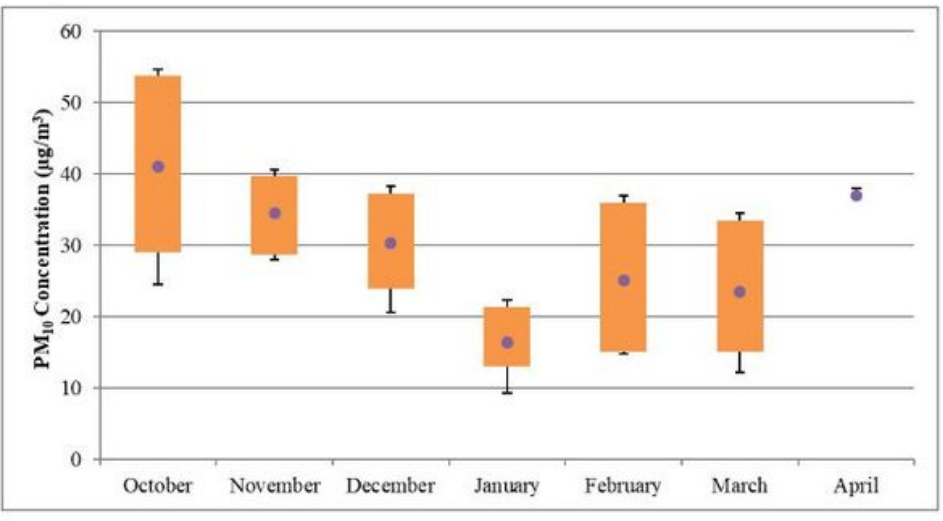

b

\section{Figure 5}

(a) PM2.5 Mean Concentration Per Month (b) Mean PM10 Concentration Per Month 


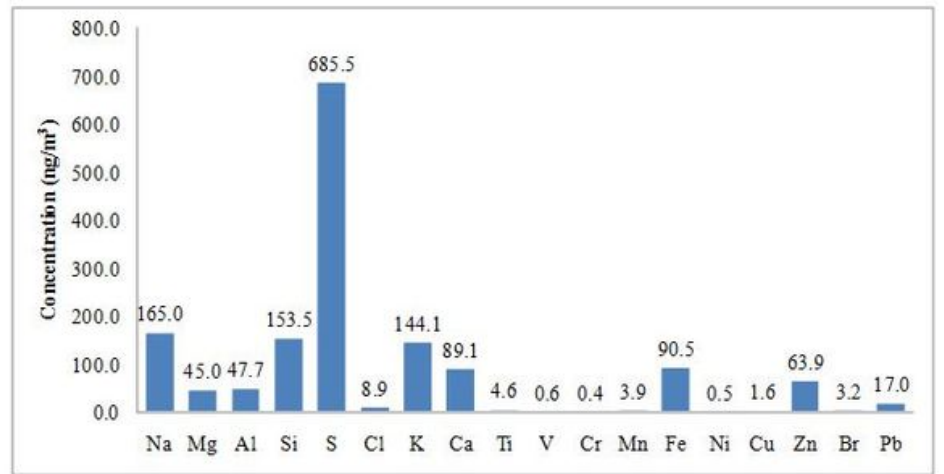

a

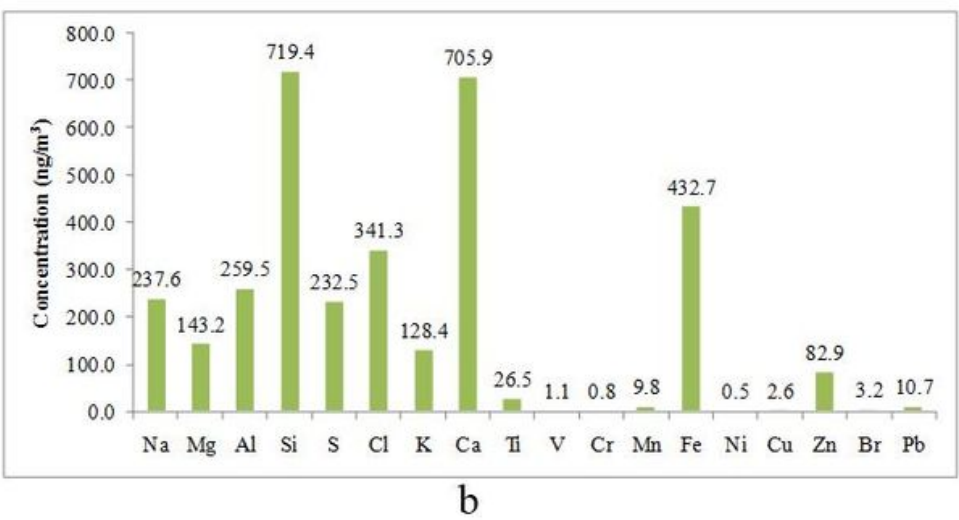

Figure 6

(a) PM2.5 Elemental Concentrations (b) PM2.5-10 Elemental Concentrations



a

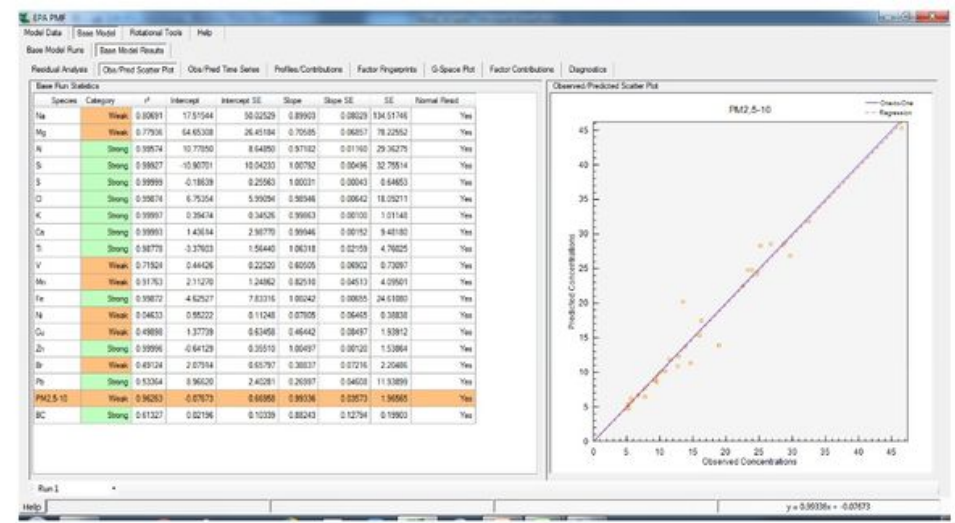

b

Figure 7

(a) Regression for PM2.5 (b) Regression for PM2.5-10 


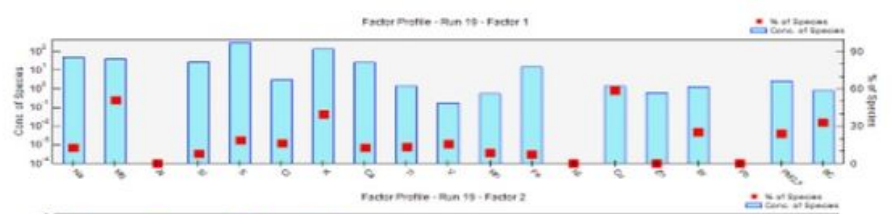

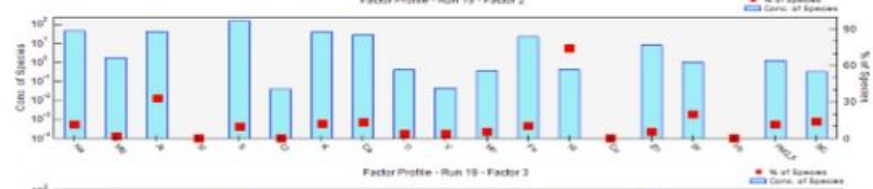

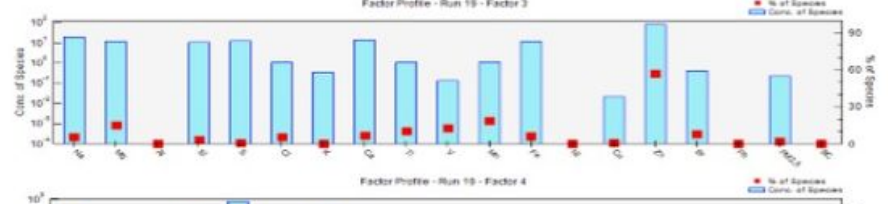

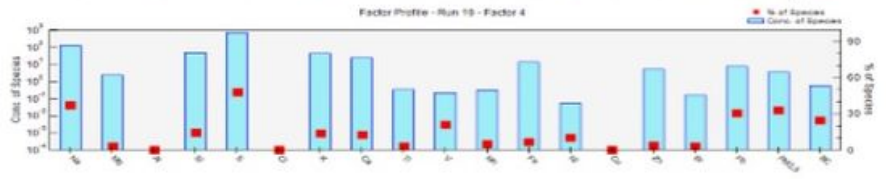

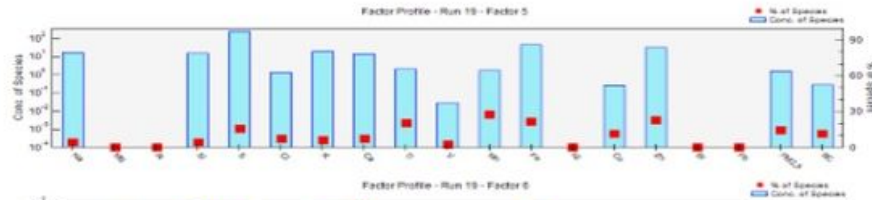

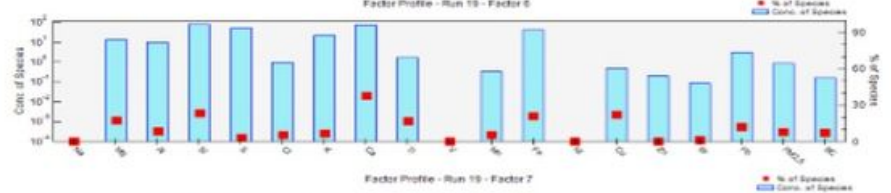




a

\section{Figure 8}

Factor Profiles (a) PM2.5 (b) PM2.5-10

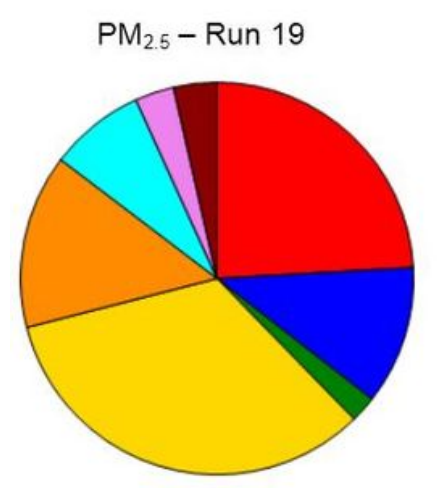

Factor $6=$

$\square$ Factor $7=0.34774(3.2 \%)$

Dactor $8=0.38602(3.6 \%)$



b



Factor Contribution $>0.05 \%$

口 Factor $1=4.55660(28.8 \%)$

Factor $2=5.07780(32.1 \%)$

Factor $3=0.59526(3.8 \%)$

$\square$ Factor $4=0.57990$ (3.7\%)

$\square$ Factor $5=1.21950(7.7 \%)$

$\square$ Factor $6=2.21770(14.0 \%)$

a 
Factor Contributions to (a) PM2.5 (b) PM2.5-10


$\mathrm{g}$



h

Figure 10

Estimated Source Area of PM2.5 (a) Factor 1 (b) Factor 2 (c) Factor 3 (d) Factor 4 (e) Factor 5 (f) Factor 6 (g) Factor 7 (h) Factor 8
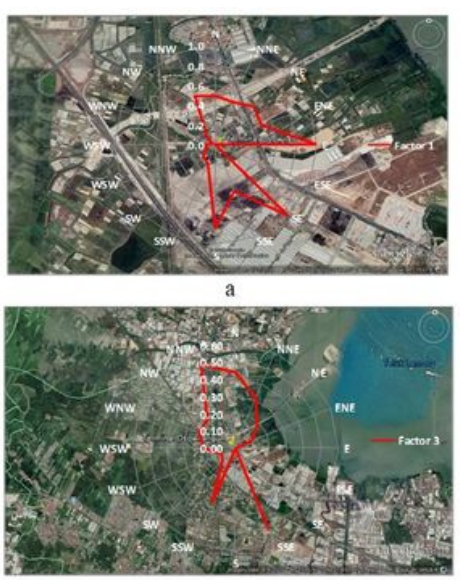

c
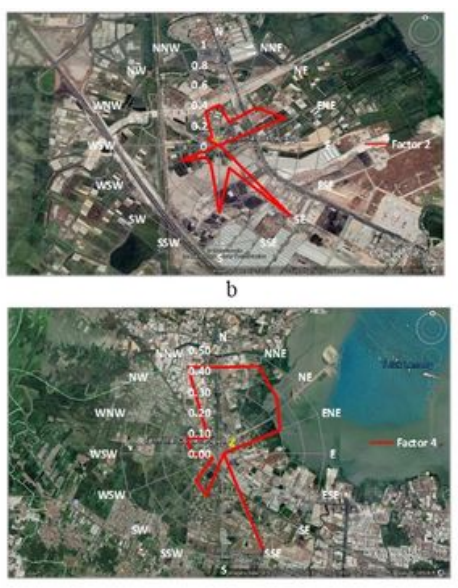

d


g

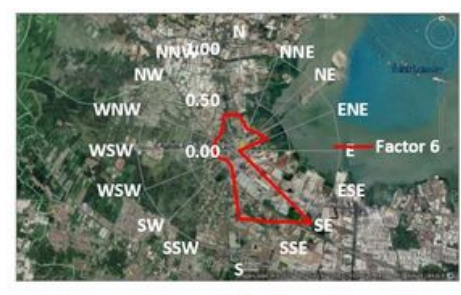

f

\section{Figure 11}

Estimated Source Area of PM2.5-10 (a) Factor 1 (b) Factor 2 (c) Factor 3 (d) Factor 4 (e) Factor 5 (f) Factor 6 (g) Factor 7 